\title{
MATERNAL INFLUENCE ON POSTIMPLANTATION SURVIVAL IN INBRED RATS*
}

\author{
DONALD V. CRAMER AND THOMAS J. GILL, III \\ Department of Pathology, University of Pittsburgh School of Medicine, \\ Pittsburgh, Pennsylvania 15261, U.S.A.
}

(Received 6th Fanuary 1975)

The derivation and maintenance of inbred strains of animals is frequently difficult or impossible due to reductions in litter size and viability of the offspring. Reductions in litter size might be expected from adverse genetic or environmental effects on components of the reproductive cycle including the ovulation rate, the rate of preimplantation mortality of the zygote and the rate of postimplantation mortality of the embryo. In some strains of inbred mice, the reduction in litter size is largely due to postimplantation losses (Lyon, 1959; Krzanowska, 1960; McCarthy, 1965, 1967). When female mice from inbred strains were mated to males of another strain, the incidence of postimplantation mortality was significantly reduced (McCarthy, 1965). It has been suggested (Lyon, 1959; McCarthy, 1965) that this wastage is the result of an increased number of recessive lethal genes, either stabilized in the strain or recent lethal mutations undergoing segregation. The implication is that the high rate of postimplantation mortality is the result of the poor genetic constitution of the young and that the maternal contribution should have little effect on the number of early deaths. On the other hand, studies involving the mouse (Krzanowska, 1960; Bradford \& Nott, 1969) and rabbit (Hammond, 1928) present some evidence that the maternal environment may be involved in determining the rate of embryonic mortality.

In rats, we have observed a high rate of both preimplantation and postimplantation mortality in the inbred ACI strain. Preimplantation losses were $25.8 \%$ of the total number of ova shed in normal ACI females (118 implantations $1159 \mathrm{CL}$ ) and are approximately equal to the rate of postimplantation mortality. To examine any effect of genotype in determining the increase in postimplantation mortality, we conducted a series of breeding experiments utilizing the ACI and F344 inbred strains (Microbiological Associates, Bethesda, Maryland). In each mating combination, one male was caged with three females for a period of 5 days. The females were killed 12 days later, and the number of viable and non-viable implantation sites were recorded (12 to 17 days gestation). Urogenital abnormalities have been reported in the AGI strain (Morgan, 1953; Deringer \& Heston, 1956; Fujikura, 1970) and, at the termination of the experiment, animals with abnormalities were eliminated from the data to reduce the potential influence of this defect on the mortality rate. A randomly

\footnotetext{
* Reprint requests and correspondence to: Dr Donald V. Cramer.
} 
outbred strain of Wistar rats (Charles River Breeding Laboratories, Inc., Wilmington, Massachusetts) was examined for comparison.

The rate of postimplantation mortality in the various parental, hybrid and back-cross matings is presented in Table 1 . In the parental combinations, the rate of wastage in the ACI strain was significantly higher than in either the F344 or Wistar strains in which it was similar to that observed in mice (McCarthy, 1965) and in other strains of rats (Chernoff, 1973; Beaudoin, 1973). In the $F_{1}$ hybrid matings, the embryonic mortality was high when the mother was of the ACI strain. When the maternal contribution was from the F344 strain, there was no excessive mortality. Mortality rates were also low when the hybrid offspring from these matings were intercrossed to produce the $F_{2}$ generation. When the $F_{1}$ hybrid offspring were back-crossed in the eight possible combinations, excessive mortality was observed only when the maternal strain was ACI. All other combinations, including those with potentially equal amounts

Table 1. Postimplantation mortality in the inbred ACI and F344 rat and in the outbred Wistar rat

\begin{tabular}{|c|c|c|c|c|c|}
\hline $\begin{array}{l}\text { Mating combination } \\
\qquad\left(\$ \times \delta^{\star}\right)^{*}\end{array}$ & $\begin{array}{l}\text { No of } \\
\text { litters }\end{array}$ & $\begin{array}{c}\text { Total no. of } \\
\text { implantationslitter } \\
(\text { Mean } \pm S . E .)\end{array}$ & $\begin{array}{c}\text { Total no. of } \\
\text { deadllitter } \\
(\text { Mean } \pm \text { S.E. })\end{array}$ & $\begin{array}{c}\text { Total } \\
\text { mortality } \\
(\%)\end{array}$ & $\begin{array}{c}\text { Comparison with } \\
F_{344}^{3} \text { strain } \\
(\mathrm{P} \text { value }) \dagger\end{array}$ \\
\hline $\begin{array}{l}\mathbf{F} \times \mathbf{F} \\
\mathbf{A} \times \mathbf{A} \\
\mathbf{W} \times \mathbf{W}\end{array}$ & $\begin{array}{l}19 \\
88 \\
25\end{array}$ & $\begin{array}{r}9 \cdot 37 \pm 0.58 \\
6 \cdot 31 \pm 0 \cdot 23 \\
12 \cdot 36 \pm 0.71\end{array}$ & $\begin{array}{l}0.37 \pm 0.16 \\
1 \cdot 12 \pm 0.12 \\
0.68 \pm 0.15\end{array}$ & $\begin{array}{r}3 \cdot 9 \\
17 \cdot 8 \\
5 \cdot 5\end{array}$ & $\begin{array}{c}<0.01 \\
\text { N.S. }\end{array}$ \\
\hline $\begin{array}{c}\mathrm{A} \times \mathrm{F} \\
\mathrm{F} \times \mathrm{A} \\
\mathrm{AF} \times \mathrm{AF} \\
\mathrm{FA} \times \mathrm{FA}\end{array}$ & $\begin{array}{l}13 \\
16 \\
15 \\
12\end{array}$ & $\begin{array}{r}8.08 \pm 0.32 \\
9.25 \pm 0.70 \\
10.00 \pm 0.94 \\
10.83 \pm 0.25\end{array}$ & $\begin{array}{l}1.39 \pm 0.32 \\
0.56 \pm 0.23 \\
0.20 \pm 0.15 \\
0.25 \pm 0.19\end{array}$ & $\begin{array}{r}17 \cdot 1 \\
6 \cdot 1 \\
2 \cdot 0 \\
2 \cdot 3\end{array}$ & $\begin{array}{l}<0.01 \\
\text { N.S. } \\
\text { N.S. } \\
\text { N.S. }\end{array}$ \\
\hline $\begin{aligned} \mathbf{A} & \times \mathbf{A F} \\
\mathbf{F} & \times \mathbf{F A} \\
\mathbf{F A} & \times \mathbf{A} \\
\mathbf{A F} & \times \mathbf{F} \\
\mathbf{A} & \times \mathbf{F A} \\
\mathbf{F} & \times \mathbf{A F} \\
\mathrm{FA} & \times \mathbf{F} \\
\mathrm{AF} & \times \mathbf{A}\end{aligned}$ & $\begin{array}{r}17 \\
13 \\
15 \\
11 \\
7 \\
12 \\
7 \\
14\end{array}$ & $\begin{array}{r}6.94 \pm 0.63 \\
10.54 \pm 0.92 \\
9.67 \pm 0.35 \\
9.91 \pm 0.44 \\
7.00 \pm 0.33 \\
9.25 \pm 0.75 \\
11.71 \pm 0.39 \\
10.50 \pm 0.76\end{array}$ & $\begin{array}{l}1.59 \pm 0.33 \\
0.85 \pm 0.20 \\
0.40 \pm 0.22 \\
0.82 \pm 0.31 \\
1.14 \pm 0.50 \\
0.00 \pm 0.00 \\
0.71 \pm 0.31 \\
0.50 \pm 0.18\end{array}$ & $\begin{array}{r}22 \cdot 9 \\
8 \cdot 0 \\
4 \cdot 1 \\
8 \cdot 3 \\
16 \cdot 3 \\
0 \cdot 0 \\
6 \cdot 1 \\
4 \cdot 8\end{array}$ & $\begin{aligned}<0.01 \\
<0.05 \\
\text { N.S. } \\
<0.05 \\
<0.01 \\
<0.05 \\
\quad \text { N.S. } \\
\quad \text { N.S. }\end{aligned}$ \\
\hline
\end{tabular}

* The abbreviations are A, ACI ; F, F344 and W, Wistar random bred. In hybrid animals, the maternal strain abbreviation is listed first.

$\dagger$ The degree of significance using the $\chi^{2}$ method, where $P>0.05$ is not significant (N.S.), $0.01<P \leqslant 0.05$ is of questionable significance and $P \leqslant 0.01$ is significant.

of genetic information derived from the $\mathrm{ACI}$ strain (i.e. $\mathrm{FA} \times \mathrm{A}$ and $\mathrm{AF} \times \mathrm{A}$ matings), were associated with low rates of postimplantation mortality. In six breeding combinations--three parental, two back-cross and the $\mathrm{F}_{2}$ generation-there was no significant alteration in the number of male (434) or female (466) offspring as a result of embryonic mortality.

The increased rates of postimplantation mortality in the ACI strain could be the result of a defective embryonic genotype, a lethal maternal effect or the interaction of both. There is no evidence that the high rate of embryonic mortality in the ACI strain is the result of a genetic defect in the developing young. When ACI females were outcrossed to F344 males, there was no significant reduction in the rate of embryonic mortality. Similarly, the distribution of 
I'LATE 1
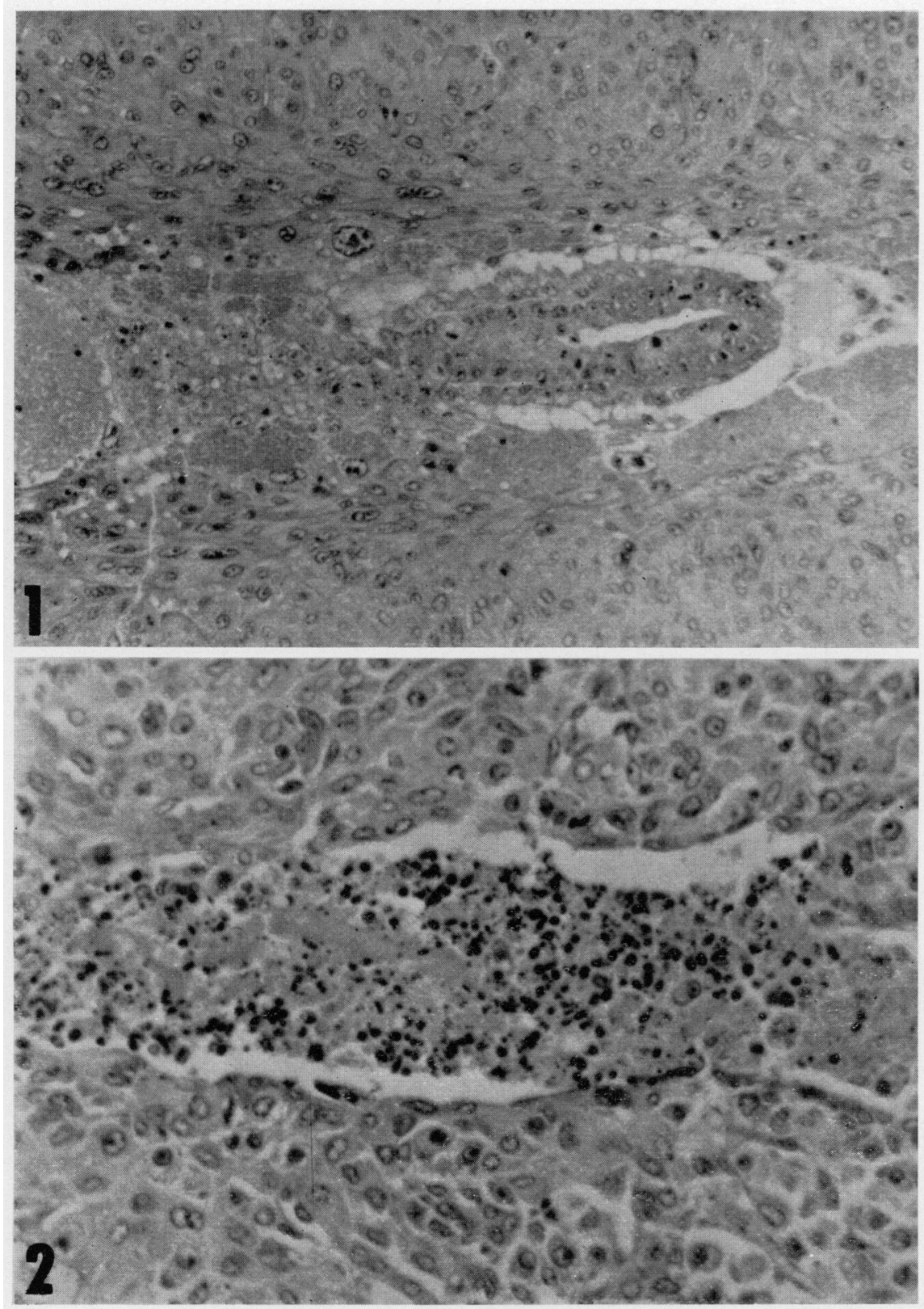

Fig. I. Small 9-day-old rat embryo of the ACI strain with disorganized ectoplacental cone.

FIG. 2. Necrotic $9 \frac{1}{2}$-day-old cmbryo of the ACI strain.

(lacing p. 318) 
the mortality rates in the reciprocal hybrid and back-cross matings was compatible with a strong maternal influence on the postimplantation survival of the embryo rather than a defect in the embryo. If single or multiple autosomal lethal genes were acting in the embryo, the rate of survival would not be affected differently in reciprocal $F_{1}$ matings. In addition, the back-cross combinations involving equal amounts of genetic information $(\mathrm{A} \times \mathrm{AF}$ versus $\mathrm{AF} \times \mathrm{A}$ and $\mathrm{A} \times \mathrm{FA}$ versus $\mathrm{FA} \times \mathrm{A}$ ) should have similar rates of embryonic losses. The findings in this study stand in contrast to the evidence in some mice that the genotype of the embryo may be responsible for postimplantation mortality. In the CBA and R111 strains of mice, significant reductions in the prevalence of postimplantation mortality were produced by outcrossing to other inbred strains (McCarthy, 1965), presumably due to improved heterozygote survival. McCarthy (1965) suggested that these inbred strains of mice suffer a high rate of embryonic mortality as the result of the accumulation of a number of homozygous recessive genes which reduce viability. While such a mechanism may be operative in the CBA and RI11 strains of mice, it does not appear to explain the findings in the ACI strain of rats. The type of maternal influence on embryonic mortality which we have observed in the ACI strain has also been reported in various strains of mice in which the number of embryonic deaths depended upon the genotype of the female and was not affected by the genotype of the male (Krzanowska, 1960).

Balanced chromosomal abnormalities could also be associated with early embryonic mortality, but the patterns of wastage among the various breeding combinations would make this an unlikely possibility. Translocations and inversions may be associated with high rates of prenatal mortality by virtue of the aneuploidy observed in the gametes and in the developing offspring. Translocations have received the greatest amount of attention, particularly in man (Chandley, Christie, Fletcher, Frackiewicz \& Jacobs, 1972) and mouse (Snell, 1946; Carter, Lyon \& Phillips, 1955; Tettenborn \& Gropp, 1970; Miller \& Miller, 1972; Cattanach \& Moseley, 1973). In the mouse, translocations established within strains are associated with postimplantation mortality when these strains are outcrossed. Incrosses between animals homozygous for the translocations do not have reduced fertility, while intercrosses between hybrids having the translocation display reduced fertility as the result of increases in embryonic mortality (Cattanach \& Moseley, 1973). If this were the case in our experiments, the matings between reciprocal $\mathrm{F}_{1}$ hybrids $(\mathrm{AF} \times \mathrm{AF}$ and $F A \times F A)$ and the back-crosses between $A C l$ males and their hybrid female offspring should be associated with increased embryonic mortality. Since these crosses produced essentially normal mortality rates, a chromosomal translocation within this strain is quite unlikely.

The embryos die earlier than the 12th day after conception, because the implantation sites of affected individuals are distinctly smaller than those of normal embryos at 12 days of gestation. Histological studies were performed on a total of forty-four ACI embryos collected at 12-hr intervals from $8 \frac{1}{2}$ to $9 \frac{1}{2}$ days gestation. Vaginal smears were taken at 09.00 hours, and conception was assumed to have occurred at the midnight preceding the detection of spermatozoa. Uteri and their implantation sites were collected from twelve 
females selected at random, fixed in Stieve's solution and serially sectioned at $4 \mu \mathrm{m}$. No morphological abnormalities could be detected at $8 \frac{1}{2}$ days gestation (eight embryos). At 9 days gestation, two of eight embryos examined were abnormal. In one case, the developing embryo was smaller than expected, primarily as the result of the failure of the extraembryonic ectoderm to become established (Pl. 1, Fig. 1). The second embryo was necrotic, and only cellular débris and infiltrating polymorphonuclear leucocytes remained. Twentyeight embryos were examined at $9 \frac{1}{2}$ days gestation, and abnormalities could be detected in five $(17.9 \%)$. One embryo had a bilobed blastocystic vesicle surrounding a single, disorganized ectoplacental cone. The remaining four embryos were dead and displayed variable degrees of necrosis and infiltration by polymorphonuclear leucocytes (PI. 1, Fig. 2). Occasional trophoblastic giant cells (one embryo) or portions of the ectoplacental cone (one embryo) could also be seen. In women (Hertig, Rock \& Adams, 1956) and in rats (Pritchard \& Huggett, 1947), the fetal membranes persist after the death of the embryo whereas, in the ACl strain, the two die simultaneously.

The breeding data presented show that the high rate of postimplantation mortality depends upon the maternal genotype. The genetic mechanism for this effect appears to be limited in its expression to the female and could be explained by a homozygous single recessive gene, a sex-linked recessive gene or multiple genes acting in concert and exhibiting a threshold effect. An autosomal or sex-linked dominant gene with complete penetrance is not compatible with the low rate of embryonic mortality in those combinations involving hybrid females. The embryonic mortality occurs early in gestation with the simultaneous death of the embryo and its membranes. It would appear, therefore, that the effect of the maternal genotype on postimplantation mortality in this strain is the failure of the maternal uterine environment to support the pregnancy rather than a direct effect on the embryo or the presence of a defect in its genetic constitution.

This work was supported by a grant from the Samuel and Emma Winters Foundation. We wish to thank Mrs Ruth Alexander for her technical assistance and Dr Joy Palm and Dr Gilbert S. Omenn for their helpful discussions.

\section{REFERENCES}

BEAUDOIN, A. R. (1973) Teratogenic activity of 2-amino-1,3,4-thiadiazole hydrochloride in Wistar rats and the protection afforded by nicotinamide. Teratology, 7, 65-72.

Bradford, G. E. \& Nott, G. F. G. (1969) Genetic control of ovulation rate and embryo survival in mice. Il. Effects of crossing selected lines. Genetics, Princeton, 63, 907-918.

Garter, T. G., Lyon, M. F. \& Phillips, R. J. S. (1955) Gene-tagged chromosome translocations in eleven stocks of mice. 7 . Genet. 53, 154-166.

Cattanach, B. M. \& Moseley, H. (1973) Nondisjunction and reduced fertility caused by the tobacco mouse metacentric chromosomes. Cytogenet. Cell Genet. 12, 264-287.

Ghandley, A. C., Ghristie, S., Fletcher, J., Frackiewicz, A. \& Jacobs, P. A. (1972) Translocation heterozygosity and associated subfertility in man. Cytogenetics, 11, 516-533.

Chernofr, N. (1973) Teratogenic effects of cadmium in rats. Teratology, 8, 29-32.

Deringer, M. K. \& Heston, W. E. (1956) Abnormalities of urogenital system in strain A $\times$ C line 9935 rats. Proc. Soc. exp. Biol. Med. 91, 312-314.

FujIKURA, T. (1970) Kidney malformations in fetuses of A $\times \mathrm{C}$ line 9935 rats. Teratology, 3, 245-249.

Hammond, J. (1928) Die Kontrolle der Fruchtbarkeit bei tieren. Zuchtungskunde, 3, 523-547. 
Hertig, A. J., Rock, J. \& Adams, E. C. (1956) A description of 34 human ova within the first 17 days of development. Am. F. Anat. 98, 435-493.

Krzanowska, H. (1960) Early embryonal mortality in inbred lines of mice and their crosses. Bull. Soc. r. belge Gynec. Obstét. 30, 719-728.

Lyon, M. F. (1959) Some evidence concerning the "mutational load" in inbred strains of mice. Heredity, Lond. 12, 341-352.

McCarthy, J. G. (1965) The effect on litter size of crossing inbred strains of mice. Genetics, Princeton, $51,217-222$.

MaCarthy, J. C. (1967) The effects of inbreeding on the components of litter size in mice. Genet. Res. $10,73-80$.

Mrllek, D. A. \& Miller, O. J. (1972) Chromosome mapping in the mouse. Science, N.Y. 178, 949955.

Morgan, W. C. (1953) Inherited congenital kidney absence in an inbred strain of rats. Anat. Rec. $115,635-639$.

Prttchard, J. J. \& HuggetT, A.St. G. (1947) Experimental foetal death in the rat: histological changes in the membranes. F. Anat., Lond. 81, 212-228.

SNell, G. D. (1946) An analysis of translocations in the mouse. Genetics, Princeton, 31, 157-180.

Tetrenborn, U. \& Gropp, A. (1970) Meiotic nondisjunction in mice and mouse hybrids. Cytogenetics, 9, 272-283. 